\title{
The tropospheric processing of acidic gases and hydrogen sulphide in volcanic gas plumes as inferred from field and model investigations
}

\author{
A. Aiuppa ${ }^{1,2}$, A. Franco ${ }^{1}$, R. von Glasow ${ }^{3, *}$, A. G. Allen ${ }^{4}$, W. D'Alessandro ${ }^{2}$, T. A. Mather ${ }^{5}$, D. M. Pyle ${ }^{5}$, and \\ M. Valenza ${ }^{1,2}$ \\ ${ }^{1}$ Dipartimento CFTA, Università di Palermo, Palermo, Italy \\ ${ }^{2}$ INGV - Sezione di Palermo, Palermo, Italy \\ ${ }^{3}$ Institut für Umweltphysik, University of Heidelberg, Germany \\ ${ }^{4}$ School of Geography, Earth and Environmental Sciences, University of Birmingham, UK \\ ${ }^{5}$ Earth Science Department, University of Oxford, UK \\ *now at: School of Environmental Sciences, University of East Anglia, Norwich, UK
}

Received: 21 September 2006 - Published in Atmos. Chem. Phys. Discuss.: 21 November 2006

Revised: 14 February 2007 - Accepted: 1 March 2007 - Published: 13 March 2007

\begin{abstract}
Improving the constraints on the atmospheric fate and depletion rates of acidic compounds persistently emitted by non-erupting (quiescent) volcanoes is important for quantitatively predicting the environmental impact of volcanic gas plumes. Here, we present new experimental data coupled with modelling studies to investigate the chemical processing of acidic volcanogenic species during tropospheric dispersion. Diffusive tube samplers were deployed at Mount Etna, a very active open-conduit basaltic volcano in eastern Sicily, and Vulcano Island, a closed-conduit quiescent volcano in the Aeolian Islands (northern Sicily). Sulphur dioxide $\left(\mathrm{SO}_{2}\right)$, hydrogen sulphide $\left(\mathrm{H}_{2} \mathrm{~S}\right)$, hydrogen chloride $(\mathrm{HCl})$ and hydrogen fluoride (HF) concentrations in the volcanic plumes (typically several minutes to a few hours old) were repeatedly determined at distances from the summit vents ranging from 0.1 to $\sim 10 \mathrm{~km}$, and under different environmental conditions. At both volcanoes, acidic gas concentrations were found to decrease exponentially with distance from the summit vents (e.g., $\mathrm{SO}_{2}$ decreases from $\sim 10000 \mu \mathrm{g} / \mathrm{m}^{3}$ at $0.1 \mathrm{~km}$ from Etna's vents down to $\sim 7 \mu \mathrm{g} / \mathrm{m}^{3}$ at $\sim 10 \mathrm{~km}$ distance), reflecting the atmospheric dilution of the plume within the acid gas-free background troposphere. Conversely, $\mathrm{SO}_{2} / \mathrm{HCl}$, $\mathrm{SO}_{2} / \mathrm{HF}$, and $\mathrm{SO}_{2} / \mathrm{H}_{2} \mathrm{~S}$ ratios in the plume showed no systematic changes with plume aging, and fit source compositions within analytical error. Assuming that $\mathrm{SO}_{2}$ losses by reaction are small during short-range atmospheric transport within quiescent (ash-free) volcanic plumes, our observations suggest that, for these short transport distances, atmospheric reactions for $\mathrm{H}_{2} \mathrm{~S}$ and halogens are also negligible. The onedimensional model MISTRA was used to simulate quantita-

Correspondence to: A. Aiuppa

(aiuppa@unipa.it)
\end{abstract}

tively the evolution of halogen and sulphur compounds in the plume of Mt. Etna. Model predictions support the hypothesis of minor $\mathrm{HCl}$ chemical processing during plume transport, at least in cloud-free conditions. Larger variations in the modelled $\mathrm{SO}_{2} / \mathrm{HCl}$ ratios were predicted under cloudy conditions, due to heterogeneous chlorine cycling in the aerosol phase. The modelled evolution of the $\mathrm{SO}_{2} / \mathrm{H}_{2} \mathrm{~S}$ ratios is found to be substantially dependent on whether or not the interactions of $\mathrm{H}_{2} \mathrm{~S}$ with halogens are included in the model. In the former case, $\mathrm{H}_{2} \mathrm{~S}$ is assumed to be oxidized in the atmosphere mainly by $\mathrm{OH}$, which results in minor chemical loss for $\mathrm{H}_{2} \mathrm{~S}$ during plume aging and produces a fair match between modelled and measured $\mathrm{SO}_{2} / \mathrm{H}_{2} \mathrm{~S}$ ratios. In the latter case, fast oxidation of $\mathrm{H}_{2} \mathrm{~S}$ by $\mathrm{Cl}$ leads to $\mathrm{H}_{2} \mathrm{~S}$ chemical lifetimes in the early plume of a few seconds, and thus $\mathrm{SO}_{2}$ to $\mathrm{H}_{2} \mathrm{~S}$ ratios that increase sharply during plume transport. This disagreement between modelled and observed plume compositions suggests that more in-detail kinetic investigations are required for a proper evaluation of $\mathrm{H}_{2} \mathrm{~S}$ chemical processing in volcanic plumes.

\section{Introduction}

Volcanic plumes are peculiar chemical/physical systems formed by the atmospheric dispersion of gases and particles released from both eruptive and quiescent volcanoes. While eruptive stratospheric plumes and their atmospheric impacts have been extensively studied in the past (e.g., Robock, 2000; Robock and Oppenheimer, 2003), the impacts of tropospheric emissions from quiescent volcanoes are far less well characterised. However it is becoming clear that these

Published by Copernicus GmbH on behalf of the European Geosciences Union. 
less dramatic but persistent emissions can have local to regional environmental impacts which may be at least as important as those of short-lived volcanic eruptions in the longterm (e.g. Delmelle, 2003; Mather et al., 2003a).

A matter of particular interest is to assess the paths and rates of chemical reactions in tropospheric volcanic plumes; these may be significantly different to those in the background atmosphere, reflecting higher temperatures, humidity, aerosol content and possibly radical production (Gerlach, 2004). Besides $\mathrm{CO}_{2}$, which is likely to be relatively inert during atmospheric dilution, volcanic degassing releases large amounts of acidic gaseous volatile species such $\mathrm{SO}_{2}$, $\mathrm{H}_{2} \mathrm{~S}$ and hydrogen halides ( $\mathrm{HCl}, \mathrm{HF}, \mathrm{HBr}$ ) (Symonds et al., 1994). As they are emitted from the vent, cooled and mixed in with atmospheric gases, these reactive species are available to take part in both homogeneous (gas-only) and heterogeneous (gas-liquid-solid) reactions. Although these reactions have been studied in detail in the laboratory, uncertainties remain when applying such results to the conditions in volcanic plumes. Recently, evidence for rapid reaction following emission, or during transport, has been found for $\mathrm{HBr}$, which is at least partially converted to $\mathrm{BrO}$ following emission (Bobrowski et al., 2007; Oppenheimer et al., 2006).

The recent detection of $\mathrm{ClO}$ and $\mathrm{OClO}$ in volcanic plumes (Lee et al., 2005; Bobrowski et al., 2007) suggests that similar reaction mechanisms (Martin et al., 2006) may also apply to emitted $\mathrm{HCl}$.

A proper evaluation of the reaction schemes involved is of fundamental importance for assessing the residence time and thus deposition rates of these acid compounds, and for quantitatively predicting the environmental impact of volcanic gas plumes. In addition, since the determination of volcanic gas composition is increasingly accomplished by remote-sensing spectroscopic methods, knowledge of atmospheric processes within volcanic plumes is required to verify the extent to which the composition of distal plumes, sampled many $\mathrm{km}$ downwind from a volcanic vent, is representative of the source composition.

The ultimate fate of much of the sulphur dioxide in volcanic plumes is thought to be conversion into sulphate aerosols (its other sinks are dry and wet deposition), which can occur via gas phase reactions (mostly via reaction with $\mathrm{OH}$ radical) or more probably on the surface of solid/liquid particles in the plume (Penkett et al., 1979; Ravinshankara, 1997). Although the rates of such reactions can vary significantly depending on temperature, humidity, insulation, and aerosol loading (Martin et al., 1986; Oppenheimer et al., 1998), first order sulphur dioxide loss rates have recently been estimated at only $\sim 4 \%$ per hour in ash-free noncondensing volcanic plumes (McGonigle et al., 2004). Hydrogen chloride and hydrogen fluoride are more soluble in water than sulphur dioxide, and hence wet deposition may cause major depletion of these species from the plume (especially during the night or in wet periods). Still, Horrocks et al. (2003) failed to detect any change in the plume $\mathrm{SO}_{2} / \mathrm{HCl}$ ratio at Masaya volcano (Nicaragua), taking FTIR measurements simultaneously at the vents and downwind of the volcano (up to $40 \mathrm{~km}$ from source, with plume ages of up to $\sim 1.5 \mathrm{~h}$ ), suggesting that there is no differential influence of tropospheric processes on plume $\mathrm{SO}_{2}$ and $\mathrm{HCl}$, at least under the conditions prevalent at a low altitude (600 $\mathrm{m}$ a.s.l.), tropical volcano $\left(11.98^{\circ} \mathrm{N}\right)$ such as Masaya. However, their measurements were limited to the drier season (December to April) in Nicaragua and during day time, when relative humidity would have been at a minimum.

Here, we test further Horrocks et al.'s (2003) suggestion that the $\mathrm{SO}_{2} / \mathrm{HCl}$ ratio in volcanic plumes is not altered by tropospheric processing over distances of tens of kms by presenting results from a series of experiments carried out on Mount Etna volcano (Sicily, Southern Italy) in the 20022005 period. Sulphur dioxide, $\mathrm{HCl}$ and $\mathrm{HF}$ time-averaged concentrations in the plume were determined repeatedly by the use of a network of diffusive tubes (Aiuppa et al., 2004) at distances from the summit vents ranging from 0.1 to $\sim 10 \mathrm{~km}$. Measurements were made during different seasons, ranging from cold and rainy periods (October-November 2003) to hot and dry periods (e.g., August 2004). By so doing, we attempt to evaluate the extent to which $\mathrm{SO}_{2} / \mathrm{HCl}$ and $\mathrm{SO}_{2} / \mathrm{HF}$ ratios are altered during atmospheric transport in a tropospheric volcanic plume under a wide range of environmental conditions. We also present the first distal "diffusive" determinations of $\mathrm{H}_{2} \mathrm{~S}$ concentrations in plumes from Mount Etna and Vulcano Island, allowing us to assess its residence time compared to $\mathrm{SO}_{2}$. Finally, the comparison of plume data with the model results from the MISTRA one-dimensional atmospheric reaction code (von Glasow et al., 2002) is used to better evaluate the chemical processing of halogen and sulphur compounds in Mt. Etna's plume.

\subsection{Introduction to field sites}

Mount Etna (Fig. 1) is the largest (summit $3.3 \mathrm{~km}$ a.s.l.; base $60 \times 40 \mathrm{~km}$ ) and most-active strato-volcano in $\mathrm{Eu}-$ rope (Bonaccorso et al., 2004). It is an excellent testsite for plume-chemistry investigations, because of the uninterrupted open-conduit passive degassing from four summit craters and the massive release of $\mathrm{SO}_{2}\left(\sim 5500 \mathrm{~T} \mathrm{~d}^{-1}\right.$; Caltabiano et al., 2004), halogens (Francis et al., 1998; Aiuppa et al., 2005a) and $\mathrm{H}_{2} \mathrm{~S}$ (Aiuppa et al., 2005b). Although Etna's plume is generally dispersed by winds at the same altitude as the emission point, it is sometimes forced by the prevailing westerly winds (Fig. 1) to flow at ground level down the volcano's slope, leading to fumigation of its upper eastern flank (Aiuppa et al., 2004; Allen et al., 2006).

Vulcano is a closed-conduit quiescent volcano in the Aeolian Islands (Fig. 2). The volcanic plume is fed by degassing from many fumaroles $\left(\mathrm{T}_{\max } \sim 450^{\circ} \mathrm{C}\right)$, with mean $\mathrm{SO}_{2}$ and $\mathrm{H}_{2} \mathrm{~S}$ emissions of $\sim 15$ and $\sim 6 \mathrm{~T} \mathrm{~d}^{-1}$, respectively (Aiuppa et al., 2005b,c). 


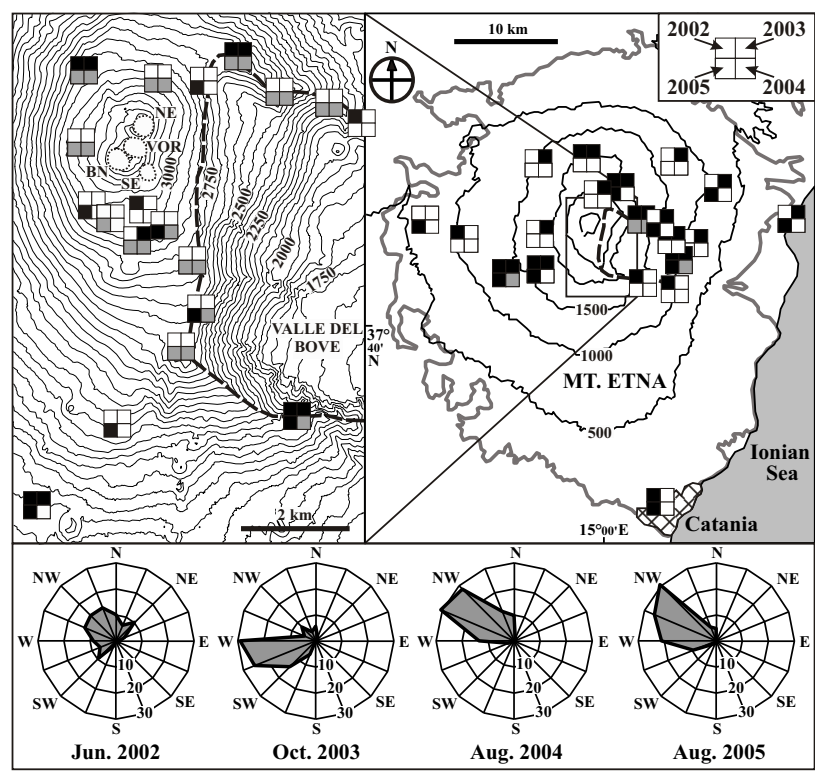

Fig. 1. Location of the sites where diffusive tubes were exposed on Etna during the different measurement campaigns. The bold grey line limits the outcrop area of Etnean volcanic products, while the dashed line shows the rim of the Valle del Bove. The summit craters are indicated with different initials: NE - North-East Crater; SE - South-East Crater; BN - Bocca Nuova; VOR - Voragine. Diffusive tubes were exposed for about one month in four campaigns on May-June 2002, October-November 2003, JulyAugust 2004 and July-August 2005. For each sampling site, the symbol is subdivided into four sectors, each referring to a different survey. A white sector indicates no sampling; a black sector indicates sampling of $\mathrm{SO}_{2}$ and halogens; a grey sector sampling of $\mathrm{SO}_{2}$, halogens and $\mathrm{H}_{2} \mathrm{~S}$. The wind rose diagrams showing the frequency of wind provenance (directions from which the wind originated are marked) at $700 \mathrm{hPa}$ during the four surveys are also shown - as based on Trapani Birgi atmospheric sounding data (http://www.weather.uwyo.edu/upperair/sounding.html).

\section{Methods}

\subsection{Measurement techniques}

Diffusive tubes have recently been shown to provide valuable information on the plume dispersion of volcanic acidic gases (Delmelle et al., 2001, 2002; Allen et al., 2002; Aiuppa et al., 2004). Diffusive tubes are passive air sampling devices that rely on the molecular diffusion of the species of interest through an entrapped air volume. A chemically-specific sorbent (an impregnated filter designed to selectively react with and capture a certain gaseous species) is placed in the closed end of an open tube, and an inert filter positioned at the inlet end to prevent turbulent transport of gases within the device, or ingress of particles. Uptake of the species of interest by the sorbent creates a concentration gradient inside the tube and the net flux of the sorbed gas is proportional to the am-

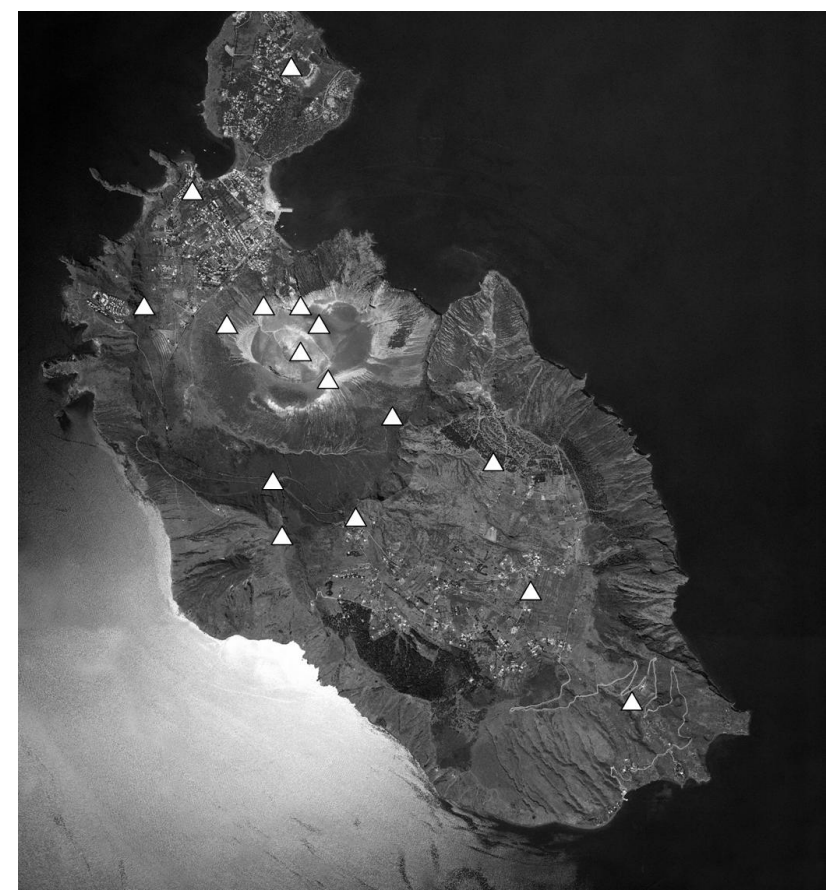

Fig. 2. Location of the sites of exposure of diffusive tubes on Vulcano Island during June-July 2005.

bient concentration. The average ambient concentration can hence be calculated from the amount of the gaseous species that is captured and the exposure time using Fick's first law of diffusion (Ferm, 2001).

The diffusive tubes used in this study for the determination of $\mathrm{SO}_{2}, \mathrm{HCl}$ and $\mathrm{HF}$ were polypropylene tubes using a paper filter impregnated with $\mathrm{NaHCO}_{3}$ in glycerol as sorbent (see Aiuppa et al., 2004 for more details). After exposure, the filter was leached in water and analyzed by ion chromatography to determine the amounts of $\mathrm{F}^{-}, \mathrm{Cl}^{-}$and $\mathrm{SO}_{4}^{2-}$ accumulated. The average $\mathrm{HF}, \mathrm{HCl}$, and $\mathrm{SO}_{2}$ concentrations in the air (precisions, $\pm 20 \%, \pm 10 \%$ and $\pm 5 \%$, respectively) during the sampling periods were then calculated (see Ayers et al., 1998 for further details). The diffusive tubes used for $\mathrm{H}_{2} \mathrm{~S}$ determination (Radiello ${ }^{\circledR}$ from Fondazione Maugeri) were of the radial sampling geometry and used a porous polyethylene cartridge impregnated with zinc-acetate as a sorbent (for details, see http://www.radiello.it/english/h2s_en.htm). The sorbed sulphide was later recovered by extraction with water, mixed with N,N-dimethyl-p-phenylenediammonium ion to yield methylene blue (measured by visible spectrophotometry).

Four field campaigns were carried out on Etna, in MayJune 2002, October-November 2003, July-August 2004 and July-August 2005. In each campaign, about 20 diffusive tubes were simultaneously exposed for about 1 month around the volcano (Fig. 1). One sampling campaign was carried out during June-July 2005 at Vulcano Island (Fig. 2). Hydrogen 


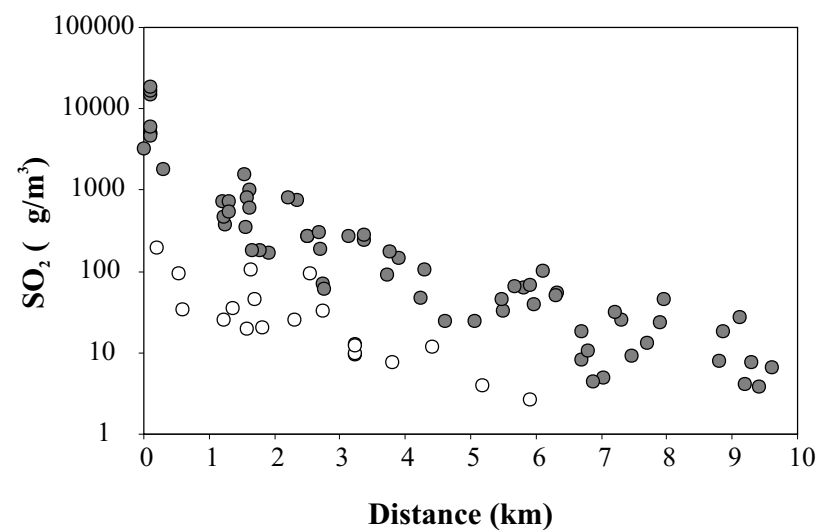

Fig. 3. $\mathrm{SO}_{2}$ concentrations in air (in $\mu \mathrm{g} / \mathrm{m}^{3}$ ) versus the corresponding distance from Etna's summit craters. Data for the four Etna campaigns are integrated. White circles, sites upwind of Etna's summit vents; grey circles, sites downwind of Etna's summit vents. Each site was assigned as upwind or downwind based on the rose diagrams of Fig. 1.

sulphide concentrations were measured at a sub-set of sampling sites during the 2004 and 2005 campaigns only (Fig. 1).

\subsection{Model description}

We used the one-dimensional model MISTRA to study the evolution of halogen and sulphur compounds in the plume of Mt. Etna. The model version that we used has been described in more detail in Bobrowski et al. (2007) and is an extension of the model presented in von Glasow et al. (2002). In brief, the model includes gas phase, aerosol and cloud droplet chemistry with a focus on halogen and sulphur chemistry. Photolysis frequencies are calculated online. Vertical mixing is treated in detail in the model, whereas horizontal mixing and entrainment of ambient air into the volcanic plume is parameterized. In this paper we discuss model runs that are based on the setup that showed best agreement with measurements at Mt. Etna of $\mathrm{BrO}$ and $\mathrm{SO}_{2}$ and $\mathrm{BrO} / \mathrm{SO}_{2}$ (run "6040", see Bobrowski et al., 2007). The initial composition of volcanic volatiles has been calculated with a thermodynamic equilibrium model under the assumption of a mixture of $60 \%$ volcanic volatiles and $40 \%$ ambient air at about $\mathrm{T}=600^{\circ} \mathrm{C}$. Model start is at local noon and the duration of the runs is $6 \mathrm{~h}$. For more details on the model and the basic setup of the runs for the modelling of volcanic plumes the reader is referred to Bobrowski et al. (2007).

In Sect. 3.2 we will discuss results from a model run where the ambient humidity has been set to $60 \%$ so that no cloud forms in the model after release of the volcanic volatiles ("cloud-free") and a second run where the ambient humidity was set to $95 \%$ resulting in cloud formation after plume release ("cloudy"). This cloud has a vertical extent of 10
$50 \mathrm{~m}$ and is present for $70 \mathrm{~min}$ after plume release, which corresponds to $42 \mathrm{~km}$ at a wind speed of $10 \mathrm{~m} / \mathrm{s}$ (see Fig. 6).

We have also conducted model runs where we included the oxidation of $\mathrm{H}_{2} \mathrm{~S}$.

\section{Results and discussion}

\subsection{Plume measurements}

Figure 3 is a plot of $\mathrm{SO}_{2}$ concentrations in air at the locations shown in Fig. 1 against the relative distances from Etna's summit craters. This clearly demonstrates the volcanic origin of $\mathrm{SO}_{2}$, since the concentrations decrease exponentially with distance from Etna's summit vents, from $\sim 10000 \mu \mathrm{g} / \mathrm{m}^{3}$ at $0.1 \mathrm{~km}$ to $\sim 7 \mu \mathrm{g} / \mathrm{m}^{3}$ at $\sim 10 \mathrm{~km}$ distance. Assuming that $\mathrm{SO}_{2}$ is virtually inert during short-term plume dispersal (McGonigle et al., 2004), this trend reflects an increasing atmospheric dilution of the plume within the $\mathrm{SO}_{2}$-free background troposphere, and further supports the idea of recurrent plume fumigation in an area $\sim 10 \mathrm{~km}$ in diameter centred east of the volcano's summit (Fig. 1), as first proposed by Aiuppa et al. (2004). The $\sim 100$-fold concentration contrast between "upwind" and "downwind" sites on Etna's flanks, confirms that plume fumigation occurs less often around Etna's western flank.

Hydrogen chloride and HF concentrations display similar decreasing (e.g., dilution) trends over the same distance interval, ranging from $\sim 800$ and $\sim 900 \mu \mathrm{g} / \mathrm{m}^{3}$, respectively, at $0.1 \mathrm{~km}$ from the vents, to below detection limit ( 0.6 and $0.35 \mu \mathrm{g} / \mathrm{m}^{3}$, respectively) at $10 \mathrm{~km}$ distance.

Molar $\mathrm{SO}_{2} / \mathrm{HCl}$ and $\mathrm{SO}_{2} / \mathrm{HF}$ ratios in air at the diffusive tube locations of Fig. 1 are shown in Fig. 4. Large variations of the ratios are observed between one campaign and another, reflecting important compositional changes at the source over time: the higher ratios in the 2002 campaign are consistent with the larger $\mathrm{SO}_{2} / \mathrm{HCl}$ and $\mathrm{SO}_{2} / \mathrm{HF}$ ratios in the near-vent summit craters' plume at that time (4.7 and 85 , respectively; Table 1). $\mathrm{SO}_{2} / \mathrm{HCl}$ and $\mathrm{SO}_{2} / \mathrm{HF}$ in the source plume were lower (and more homogeneous) during the 2003, 2004 and 2005 campaigns (Table 1). Equally, data from each campaign consistently show that there are no systematic changes (within the measurement errors) in the $\mathrm{SO}_{2} / \mathrm{HCl}$ ratios with distance (i.e. with plume aging) from the vents (Fig. 4). The mean $\mathrm{SO}_{2} / \mathrm{HCl}$ ratios (Table 1) fit source compositions within analytical uncertainty for each of the four campaigns, and suggest that, for these short transport distances, atmospheric reactions during plume transport for both species are either negligible or of the same rate. The scatter of $\mathrm{SO}_{2} / \mathrm{HF}$ ratios for each campaign is larger than for $\mathrm{SO}_{2} / \mathrm{HCl}$ ratios, as is the discrepancy from the source's composition (Table 1). However, there is still no apparent systematic distance-ratio dependence, and the scatter in the dataset seems to be more likely related to analytical uncertainties in fluoride determination, with concentrations often 
Table 1. Mean $\mathrm{SO}_{2} / \mathrm{HCl}, \mathrm{SO}_{2} / \mathrm{HF}$ and $\mathrm{SO}_{2} / \mathrm{H}_{2} \mathrm{~S}$ molar ratios from diffusive tubes for the four Etna campaigns. Standard deviations are given in parentheses. For comparison, the characteristic molar ratios in the near-vent source plume are given for each campaign (as averages of the periodic measurements performed on Etna's vents during each exposure period).

\begin{tabular}{lllllll}
\hline Campaign & \multicolumn{2}{c}{$\mathrm{SO}_{2} / \mathrm{HCl}$} & \multicolumn{2}{c}{$\mathrm{SO}_{2} / \mathrm{HF}$} & \multicolumn{2}{c}{$\mathrm{SO}_{2} / \mathrm{H}_{2} \mathrm{~S}$} \\
\hline & $\begin{array}{l}\text { Source } \\
\text { plume }\end{array}$ & $\begin{array}{l}\text { Diffusive } \\
\text { tubes }\end{array}$ & source $^{\mathrm{a}}$ & $\begin{array}{l}\text { Diffusive } \\
\text { tubes }\end{array}$ & $\begin{array}{l}\text { Source } \\
\text { plume }\end{array}$ & $\begin{array}{l}\text { Diffusive } \\
\text { tubes }\end{array}$ \\
2002 & 4.7 & $\begin{array}{l}4.9 \\
(0.9)\end{array}$ & 90 & $90(26)$ & - & - \\
2003 & 1.0 & $\begin{array}{l}1.0 \\
(0.2)\end{array}$ & 21 & $16(5)$ & - & - \\
2004 & 1.5 & $\begin{array}{l}1.7 \\
(1.0)\end{array}$ & 20 & $16(6)$ & $\sim 60$ & $60(55)$ \\
2005 & 2.2 & $\begin{array}{l}1.2 \\
(0.5)\end{array}$ & 10 & $12(3)$ & $\sim 60$ & $54(20)$ \\
& & & & & & \\
\hline
\end{tabular}

a Measurements of acidic gases in the crater's plume by filter packs (Aiuppa et al., 2005a) and this study.

${ }^{b}$ Measured by specific electrochemical sensors according to the method described in Aiuppa et al. (2005c), and assuming equal (1:1) sulphur contributions from North-east crater $\left(\mathrm{SO}_{2} / \mathrm{H}_{2} \mathrm{~S} \sim 20\right)$ and Voragine crater $\left(\mathrm{SO}_{2} / \mathrm{H}_{2} \mathrm{~S} \sim 100\right)$.

being very close to the detection limit. These observations are consistent with the usefulness of diffusive samplers for volcanic monitoring (Aiuppa et al., 2004).

Hydrogen sulphide concentrations, measured in a subset of Etna's locations during the 2004 and 2005 campaigns, are plotted against corresponding $\mathrm{SO}_{2}$ concentrations in Fig. 5. They range between $0.3-281 \mu \mathrm{g} / \mathrm{m}^{3}$ and are positively correlated with $\mathrm{SO}_{2}$ concentrations. $\mathrm{SO}_{2} / \mathrm{H}_{2} \mathrm{~S}$ ratios are highly scattered (Table 1), reflecting a combination of poor analytical accuracy of $\mathrm{H}_{2} \mathrm{~S}$ determinations $(8.7 \%$ at $2 \sigma ; \mathrm{http}: / / \mathrm{www}$. radiello.it/english/h2s_en.htm), multiple $\mathrm{H}_{2} \mathrm{~S}$ sources (fumarolic vs main vents, or natural vs anthropogenic), or complex atmospheric chemistry. Nevertheless, mean $\mathrm{SO}_{2} / \mathrm{H}_{2} \mathrm{~S}$ ratios from diffusive tubes for both campaigns (54 and 60, respectively) are in reasonable agreement with the source plume composition $(\sim 60$; Table 1$)$. Data from the Vulcano Island campaign (Fig. 5), showing consistent $\mathrm{SO}_{2} / \mathrm{H}_{2} \mathrm{~S}$ ratios in source (2.2 \pm 1.1 ; Aiuppa et al. 2005c) and distal (2.2 \pm 1.2 , this study) plumes, also point to only minor alterations of sulphur speciation during medium-term plume transport (for plume ages of $\sim 30 \mathrm{~min}$, assuming a plume travelling speed of $\sim 10 \mathrm{~km} / \mathrm{h}$ ). These results extend the earlier conclusions by Aiuppa et al. (2005b), who demonstrated that hydrogen sulfide is essentially inert in volcanic plumes on timescales of seconds to minutes.

\subsection{Model results}

\subsubsection{Halogen and $\mathrm{SO}_{2}$ chemistry}

The basic features of the plume differ in the cloud-free and cloudy model runs, as can best be seen in the evolution of $\mathrm{SO}_{2}$. The evolution of liquid water content of the cloud developing at the crater in model run "cloudy" is shown
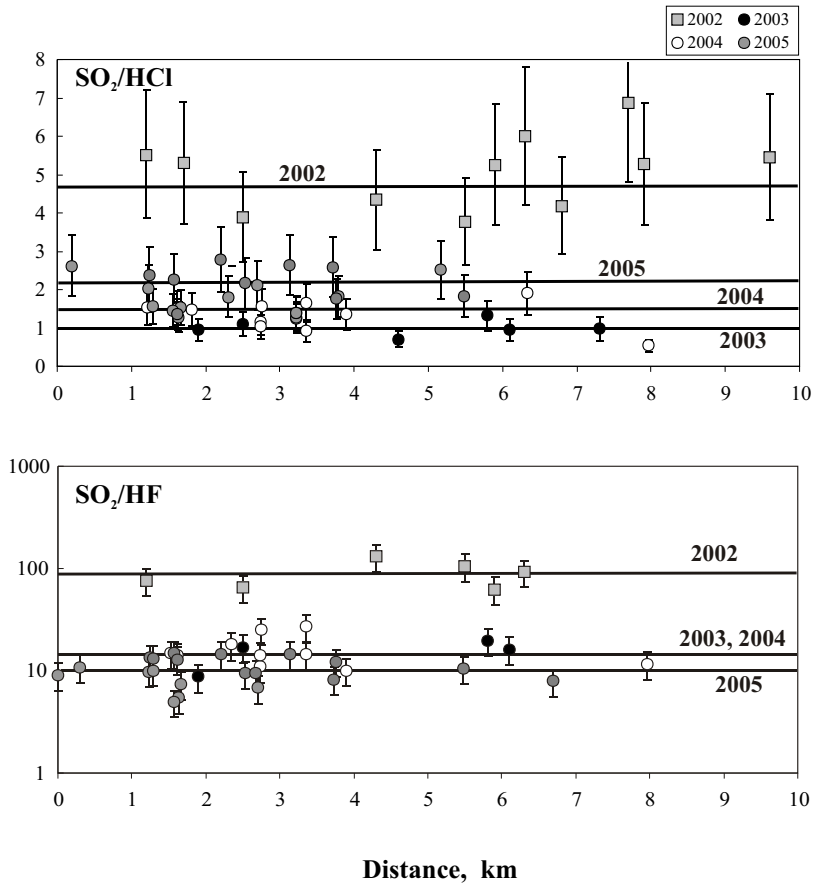

Fig. 4. $\mathrm{SO}_{2} / \mathrm{HCl}$ and $\mathrm{SO}_{2} / \mathrm{HF}$ molar ratios in air at the diffusive tube locations of Fig. 1, shown against the corresponding distance from Etna's summit vents. The horizontal solid lines indicate - for each campaign - the mean $\mathrm{SO}_{2} / \mathrm{HCl}$ and $\mathrm{SO}_{2} / \mathrm{HF}$ molar ratios in the nearvent source plume (Table 1). The diagram demonstrates contrasting compositions between the 2002 campaign (where higher $\mathrm{SO}_{2} / \mathrm{HCl}$ and $\mathrm{SO}_{2} / \mathrm{HF}$ were measured) and 2003-2005 campaigns. It also points to minor variations (within analytical uncertainty) of ratios with distance (e.g., with increasing plume travel times) in each campaign. 


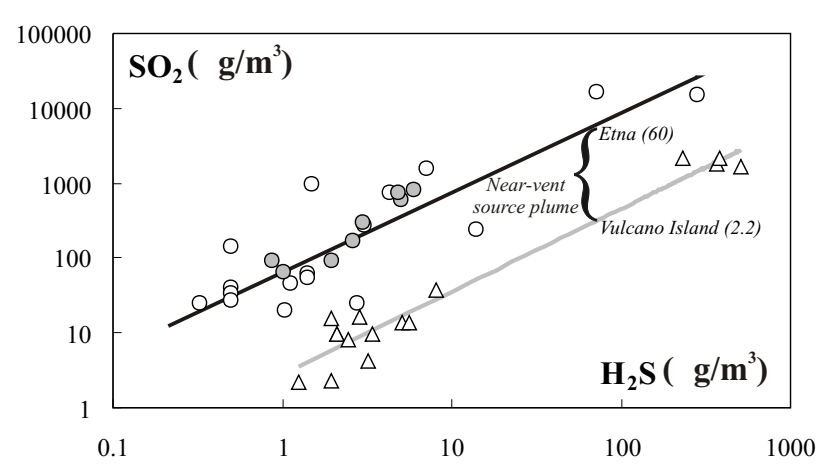

Fig. 5. Scatter diagram of $\mathrm{SO}_{2}$ versus $\mathrm{H}_{2} \mathrm{~S}$ concentrations (in $\mu \mathrm{g} / \mathrm{m}^{3}$ ), measured at a sub-set of Etna's locations (Fig. 1) in 2004 and 2005 campaigns (symbols as in Fig. 4). Data for the 2005 Vulcano Island campaign are also shown (triangles). For both Etna and Vulcano Island, the characteristic $\mathrm{SO}_{2} / \mathrm{H}_{2} \mathrm{~S}$ ratios of the near-vent source plumes (numbers in parentheses; see Table 1) are indicated by the solid diagonal lines.

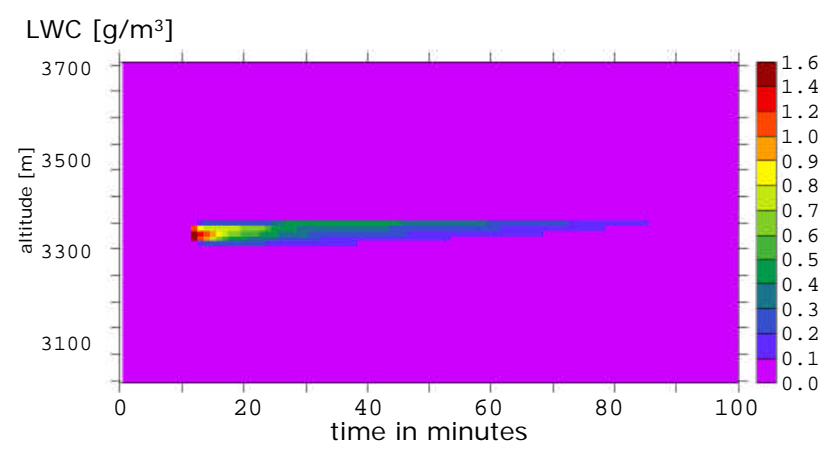

Fig. 6. Contour plot of the liquid water content of the cloud developing at the crater in model run "cloudy". Time is in minutes since model start (plume release is $11 \mathrm{~min}$ after model start) and altitude in metres.

in Fig. 6. In the cloud-free run (Fig. 7, top panel), the plume rises due to the initially high temperature of the plume $\left(\sim 600^{\circ} \mathrm{C}\right)$ and radiative heating due to absorption by the volcanic aerosols. In the cloudy run (Fig. 8, top panel), the plume descends due to long-wave cooling of the cloud-top and by additional cooling caused by the evaporation of cloud droplets. For numerical reasons we were not able to prescribe the temperature of the fresh plume in the cloudy run to $\sim 600^{\circ} \mathrm{C}$ as in the cloud-free run, but only to ambient temperatures, therefore the plume descent is somewhat stronger than it would be if thermal buoyancy effects had been included.

Due to plume dispersal, the concentration of $\mathrm{SO}_{2}$ in the core of the plume is higher than at the edges. The smaller concentrations at the plume base in the model are in the range measured with the diffusive tubes, which is consistent with the fact that the plume edges will be more likely to be in con-

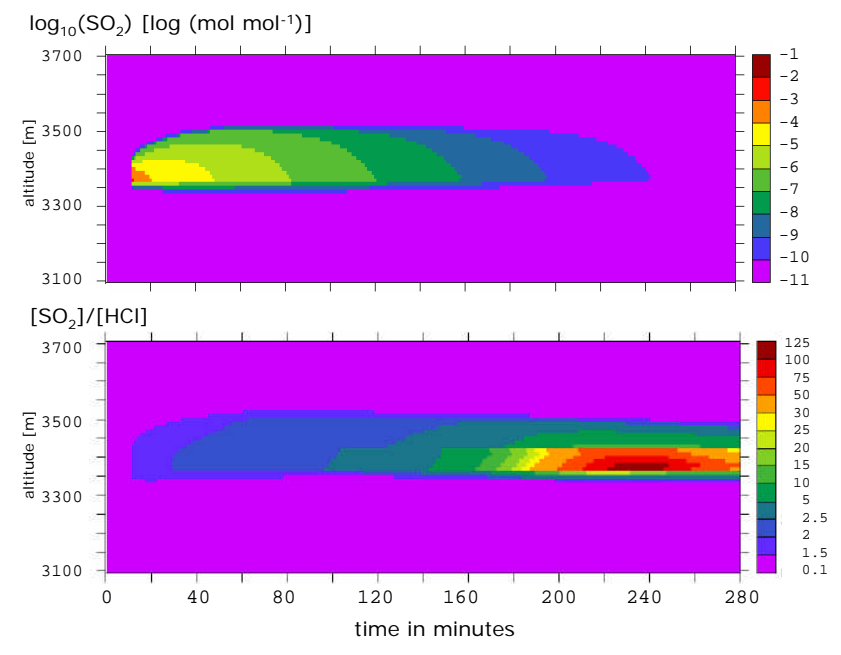

Fig. 7. Contour plot of the evolution of the $\mathrm{SO}_{2}$ and the ratio $\mathrm{SO}_{2}$ to $\mathrm{HCl}$ for the "cloud-free" model run. Time is in minutes since model start (plume release is 11 min after model start) and altitude in metres. Note the strongly non-linear contours for $\left[\mathrm{SO}_{2}\right]:[\mathrm{HCl}]$.

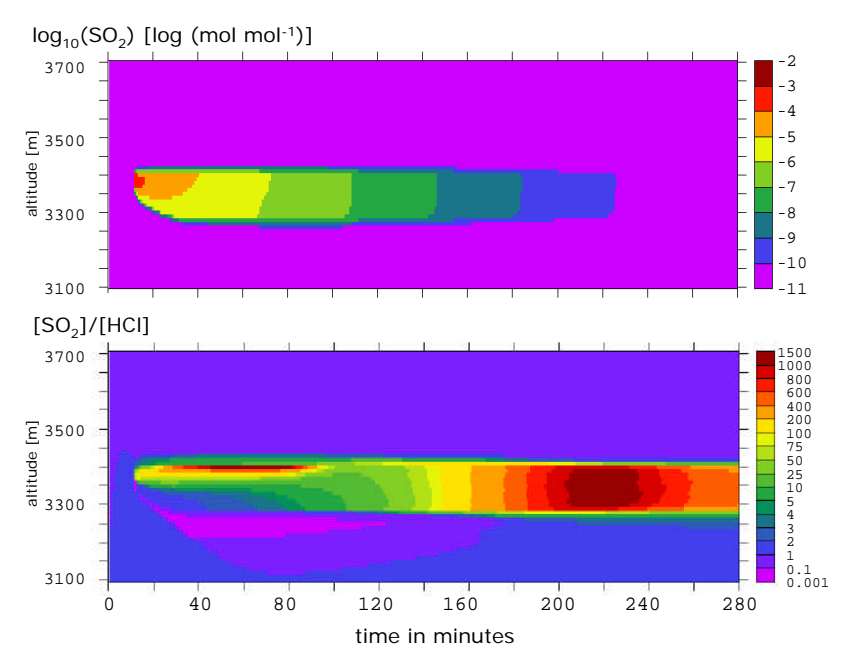

Fig. 8. Same as Fig. 8 but for the "cloudy" model run.

tact with the ground (where the diffusion tubes are located) than the core of the plume. At the altitude of Mt Etna's summit a concentration of $1 \mu \mathrm{g}\left(\mathrm{SO}_{2}\right) / \mathrm{m}^{3}$ roughly corresponds to a mixing ratio of $5 \times 10^{-10} \mathrm{~mol} / \mathrm{mol}$.

In order to compare the model results with the diffusive tube measurements presented in this paper, we show the evolution of the $\mathrm{SO}_{2} / \mathrm{HCl}$ ratio as a function of time and altitude for both the cloud-free and the cloudy run (see bottom panels of Figs. 7 and 8). The $\mathrm{SO}_{2} / \mathrm{HCl}$ ratio in the cloud-free runs is constant for approximately the first $130 \mathrm{~min}$ after plume release and it averages at about 2 , very close to the measured ratios. This matching between modelled and measured ratios further supports only minor hydrogen chloride partitioning into the liquid/solid aerosol phase, at least in cloud-free 
conditions and in the short-term (minutes). Although fluorine chemistry was not included in the modelling, we propose that similar considerations also apply to even less-reactive HF. Starting $\sim 130$ min after plume release, the $\mathrm{SO}_{2} / \mathrm{HCl}$ ratio rapidly increases in the model (note the strongly nonlinear increments of the contour lines in Fig. 7), which is due to heterogeneous cycling of $\mathrm{HCl}$ on aerosols: after this time, plume dilution has decreased the gas phase concentrations enough to make uptake onto the aerosol phase an important sink for $\mathrm{HCl}$. It should be noted, however, that model $\mathrm{ClO}$ vertical columns underestimate the measured columns by about a factor of 40 in the early plume (see Bobrowski et al., 2006), so that some uncertainty remains as to whether chlorine chemistry is properly reproduced in the model. In the case of $\mathrm{HCl}$, however, it is likely that the model captures its chemistry with some accuracy, as it is fairly un-reactive in the gas phase and its aqueous fraction is small due to the high acidity of the aerosol particles until the gas phase concentration is reduced by dilution. This is also supported by field measurements of night- (cloudy plume with $\mathrm{RH} \geq 88 \%$ ) and daytime (transparent) plume $\mathrm{SO}_{2} / \mathrm{HCl}$ ratios in the undiluted plume at the crater rim of Masaya volcano, Nicaragua (Mather et al., 2003b).

The evolution of the $\mathrm{SO}_{2}$ to $\mathrm{HCl}$ ratio in the cloudy run (see Fig. 8) is different from that in the cloud-free run. The ratio is fairly high in the cloud layers due to uptake of $\mathrm{HCl}$ in the cloud droplets, which contain a lot more water than aerosol particles. The lower, cloud-free part of the plume in these runs would seem more likely to ground though, and in this region the modelled ratio is consistent with the measurements. Even if the diffusion tubes are within a "grounded cloud", during part of the sampling time one can expect a mixture of the modelled "cloud-free" and "cloudy" conditions during sampling with the diffusion tubes which would still be consistent with the field data. These modelling results are in agreement with the relatively minor chlorine bulk deposition fluxes measured over the volcano perimeter, accounting for $\leq 1 \%$ of total emissions from the volcano (Aiuppa et al. 2006), which argue against a substantial $\mathrm{HCl}$ removal from the plume.

\subsection{2 $\quad \mathrm{H}_{2} \mathrm{~S}$ chemistry}

We already demonstrated elsewhere (Aiuppa et al., 2005b) that the measured $\mathrm{SO}_{2} / \mathrm{H}_{2} \mathrm{~S}$ ratios in the short-lived Etna's plume (plume ages of seconds to a few minutes) reflect thermodynamic equilibrium at magmatic conditions ( $\sim 11006^{\circ} \mathrm{C} ; \mathrm{P} \sim 1-10$ bars) and redox conditions buffered by the coexisting silicate melt at about the Nickel-Nickel oxide (NNO) buffer $\left(\mathrm{fO}_{2} \sim 10^{-9}\right.$ bar at $1150^{\circ} \mathrm{C}$; Metrich and Clocchiatti, 1996). Conversely, our gas-only thermodynamic equilibrium calculations with the software HSC (Outokumpu Tech., Finland) show that under " $60-40, T=600 \mathrm{~K}$ " conditions, the concentration of $\mathrm{H}_{2} \mathrm{~S}$ in the early plume should be negligible, due to much higher oxygen fugacity
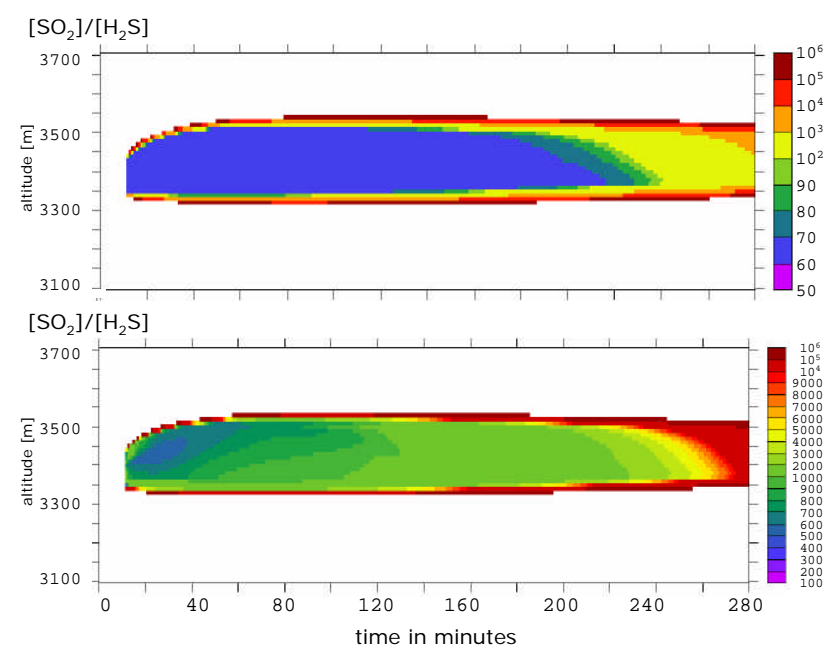

Fig. 9. Contour plot of the $\mathrm{SO}_{2}$ to $\mathrm{H}_{2} \mathrm{~S}$ ratio for a cloud-free model run without (top) and with halogen $-\mathrm{H}_{2} \mathrm{~S}$ interactions (bottom), respectively. Time is in minutes since model start (plume release is 11 min after model start) and altitude in metres.

$\left(\mathrm{fO}_{2} \sim 0.08\right.$ bar) in the air-volcanic gas mixture. This is in stark contrast to our measurements, and implies that the emitted $\mathrm{H}_{2} \mathrm{~S}$ is not fast-oxidized upon cooling and dilution in the high-temperature volcanic gas-air mixing region. Thus the assumption of thermodynamic equilibrium in the volcanic volatiles-ambient air mixture does not hold for $\mathrm{H}_{2} \mathrm{~S}$. We therefore assume that the $\mathrm{H}_{2} \mathrm{~S}$ concentration equals $\mathrm{SO}_{2} / 60$ in the fresh plume, and this was used as input data for further modelling with MISTRA code.

Typically, $\mathrm{H}_{2} \mathrm{~S}$ is assumed to be oxidized in the atmosphere mainly by $\mathrm{OH}$. Including only this reaction as chemical loss for $\mathrm{H}_{2} \mathrm{~S}$ our model results very closely reproduced the measured ratio of $\mathrm{SO}_{2} / \mathrm{H}_{2} \mathrm{~S}$ (see Fig. 9, top panel). As model ozone concentrations are strongly reduced in the early plume, the resulting $\mathrm{OH}$ concentrations are very small (see also discussion in Bobrowski et al., 2007), therefore one would expect $\mathrm{H}_{2} \mathrm{~S}$ to have a long chemical lifetime in early volcanic plumes. The halogen radicals $\mathrm{Cl}$ and $\mathrm{Br}$, however, react very rapidly with $\mathrm{H}_{2} \mathrm{~S}$ as well, leading to the production of the hydrogen sulphide radical, $\mathrm{SH}$, as in the case of $\mathrm{H}_{2} \mathrm{~S}+\mathrm{OH}$. The rate coefficient for the reaction $\mathrm{H}_{2} \mathrm{~S}+\mathrm{Cl}$ is fairly well known (Sander et al., 2006) but only one measurement has been reported for $\mathrm{H}_{2} \mathrm{~S}+\mathrm{Br}$ (Nicovich et al., 1992). In line with recent measurements of halogen oxides $(\mathrm{ClO}$, $\mathrm{OClO}, \mathrm{BrO}$ ) in volcanic plumes (Bobrowski et al., 2003, 2007; Lee et al, 2005), we also included the interactions of $\mathrm{H}_{2} \mathrm{~S}$ and its break-down products with halogens in the model.

$\mathrm{SH}$, the first break-down product of $\mathrm{H}_{2} \mathrm{~S}$, can be reduced back to $\mathrm{H}_{2} \mathrm{~S}$ by self reaction and by reaction with $\mathrm{HBr}$ (Nicovich et al., 1992) and according to the model in the first few minutes after plume release the reduction by $\mathrm{HBr}$ is indeed more important than oxidation of $\mathrm{H}_{2} \mathrm{~S}$ by $\mathrm{Br}$. The 
oxidation of $\mathrm{H}_{2} \mathrm{~S}$ by $\mathrm{Cl}$, however, is very fast leading to $\mathrm{H}_{2} \mathrm{~S}$ chemical lifetimes in the early plume of a few seconds and a drastically changing $\mathrm{SO}_{2}$ to $\mathrm{H}_{2} \mathrm{~S}$ ratios (see Fig. 9, bottom panel). This is an obvious contradiction to our measurements (Fig. 5). According to thermodynamic equilibrium calculations of the composition of the initial plume, there are significant amounts of atomic halogens in the mixture of volcanic volatiles and ambient air (see also Gerlach, 2004 and Martin et al., 2006), so that the fast oxidation of $\mathrm{H}_{2} \mathrm{~S}$ by $\mathrm{Cl}$ should also proceed at night.

Possible explanations for the mismatch between modelled and field-measured $\mathrm{SO}_{2} / \mathrm{H}_{2} \mathrm{~S}$ ratios could be that our model strongly overestimates the $\mathrm{Cl}$ concentrations in the plume. This might be due to the presence of volatile organic compounds (VOC) in the plume in substantially greater concentrations than the background free tropospheric concentrations that are included in our model. The VOC concentrations would have to be extremely high in order to reduce $\mathrm{Cl}$ atom concentrations, though, as $\mathrm{Cl}$ atom concentrations in the model are of the order of $10^{9} \mathrm{molec} / \mathrm{cm}^{3}$ in the first $10 \mathrm{~min}$ after plume release. While VOC have been shown to be actively degassed by soils and fumaroles at active volcanoes (e.g., Schwandner et al., 2004; Frische et al., 2006), no above-background VOC levels have been reported in volcanic plumes, to date. However, again it should be noted that a comparison of model results with observed column densities of $\mathrm{ClO}$, a species closely linked to $\mathrm{Cl}$, showed an underestimate of the $\mathrm{ClO}$ columns in the model. Even though we cannot exclude the possibility that we have neglected important chlorine reactions in the model that might lead to smaller chlorine atom concentrations, this is unlikely to yield a sufficiently different $\mathrm{Cl} / \mathrm{ClO}$ ratio to be consistent with the measurements of high $\mathrm{ClO}$ columns (assuming that the spatial gradients are not extraordinarily high). Another possible explanation would be rapid reduction of $\mathrm{SH}$ by $\mathrm{HCl}$ back to $\mathrm{H}_{2} \mathrm{~S}$, as is the case for bromine. For chlorine, however, this reaction is endothermic. Another complication with regard to $\mathrm{H}_{2} \mathrm{~S}$ - halogen links is the fact that the hydrogen sulphide radical is known to react rapidly with dihalogens $\left(\mathrm{Cl}_{2}, \mathrm{BrCl}\right.$, $\mathrm{Br}_{2}$ ) producing XSH (Sander et al., 2006). The fate of XSH, however, remains unknown and one can only speculate about reaction pathways and rate constants that would lead to a possible reformation of $\mathrm{H}_{2} \mathrm{~S}$.

There is currently a significant lack of information regarding the possible reactions that may be involved in halogen $\mathrm{H}_{2} \mathrm{~S}$ links in volcanic plumes so we unfortunately cannot use the model to explore our observations in more detail. Further study of the possible reactions that might be involved and their kinetics is to be encouraged.

\section{Conclusions}

Our combined experimental and modelling investigations support volcanogenic $\mathrm{HCl}$ and $\mathrm{HF}$ being essentially inert (their chemical processing being negligible compared to their reservoir within the plume) during short-term plume transport, as already hypothesised for $\mathrm{SO}_{2}$ (McGonigle et al., 2004). We suggest that $\mathrm{HCl}$ heterogeneous cycling into the aerosol phase, which is expected to be the main atmospheric sink for chlorine under plume conditions, is relatively minor under low relative humidity conditions, when chlorine partitioning into the liquid phase is limited by the high acidity of the aerosol particles (at least until the gas phase concentration is reduced by dilution). Chlorine heterogeneous cycling may be more effective under cloudy conditions, due to $\mathrm{HCl}$ uptake in cloud droplets. However, even under these conditions, the virtually-constant $\mathrm{SO}_{2} / \mathrm{HCl}$ plume ratios measured during rainy periods (e.g., October 2003), and the relatively minor chlorine bulk deposition fluxes measured over the volcano perimeter, accounting for $\leq 1 \%$ of total emissions from the volcano (Aiuppa et al., 2006), argue against a substantial $\mathrm{HCl}$ removal from the plume. Our measurements also show that $\mathrm{SO}_{2} / \mathrm{H}_{2} \mathrm{~S}$ ratios are constant (within analytical uncertainty) for plume travel distances of up to several kilometres from the summit vents, suggesting that $\mathrm{H}_{2} \mathrm{~S}$ is also conserved during short-range transport (i.e. for plume travel times of tens of minutes). This suggestion is supported by model calculations only when $\mathrm{H}_{2} \mathrm{~S}$-halogens interactions are neglected. At this stage we can only pose open questions with regard to $\mathrm{H}_{2} \mathrm{~S}$ in the plume but are unable to answer them without further information about the possible reactions involved: (1) Which reactions are able to preserve $\mathrm{H}_{2} \mathrm{~S}$ during cooling and dilution within the high-temperature $\left(>600^{\circ} \mathrm{C}\right.$ ) volcanic gas-air mixing region? (2) What is the fate of XSH? (3) What other possibly halogen related reactions could be able (like $\mathrm{HBr}$ ) to reduce $\mathrm{SH}$ to $\mathrm{H}_{2} \mathrm{~S}$ ?

Acknowledgements. TAM acknowledges the Royal Society and the Natural Environment Research Council, UK and the Leverhulme Trust for funding. RvG's work is funded by the Deutsche Forschungsgemeinschaft (DFG): Emmy-Noether Junior Research Group MarHal, GL 353-1/1,2. S. Bellomo, L. Brusca, M. Longo, F. Parello, and R. Di Paola are acknowledged for help in the field work.

Edited by: M. Ammann

\section{References}

Aiuppa, A., Bellomo, S., D’Alessandro, W., Federico, C., Ferm, M., and Valenza, M.: Volcanic plume monitoring at Mount Etna by diffusive (passive) sampling, J. Geophys. Res., 109, D21308, doi:10.1029/2003JD004481, 2004.

Aiuppa, A., Federico, C., Franco, A., Giudice, G., Gurrieri, S., Inguaggiato, S., Liuzzo, M., McGonigle, A. J. S., 
and Valenza M.: Emission of bromine and iodine from Mount Etna volcano, Geochem. Geophys. Geosyst., 6, Q08008, doi:10.1029/2005GC000965, 2005a.

Aiuppa, A., Inguaggiato, S., McGonigle, A. J. S., O’Dwyer, M., Oppenheimer, C., Padgett, M. J., Rouwet, D., and Valenza M.: $\mathrm{H}_{2} \mathrm{~S}$ fluxes from Mt. Etna, Stromboli and Vulcano (Italy) and implications for the global volcanic sulfur budget, Geochim. Cosmochim. Acta, 69-7, 1861-1871, 2005, doi:10.1016/j.gca.2004.09.018, 2005b.

Aiuppa, A.., Federico, C., Giudice, G., and Gurrieri, S.: Chemical mapping of a fumarolic field: La Fossa Crater, Vulcano Island (Aeolian Islands, Italy), Geophys. Res. Lett., 32(13), L13309, 10.1029/2005GL023207, 12 July 2005, 2005c.

Aiuppa, A., Bellomo, S., Brusca, L., D’Alessandro, W., Di Paola, R., and Longo, M.: Major-ion bulk deposition around an active volcano (Mt. Etna, Italy), Bull Volcanol, 68(3), 255-265, doi:10.1007/s00445-005-0005-x, 2006.

Allen, A. G., Oppenheimer, C., Ferm, M., Baxter, P. J., Horrocks, L. A., Galle, B., McGonigle, A. J. S., and Duffell, H. J.: Primary sulfate aerosol and associated emissions from Masaya Volcano, Nicaragua, J. Geophys. Res., 107(D23), 4682, doi:10.1029/2002JD002120, 2002.

Allen, A. G., Mather, T. A., McGonigle, A. J. S., Aiuppa, A., Delmelle, P., Davison, B., Bobrowski, N., Oppenheimer, C., Pyle, D. M., and Inguaggiato, S.: Sources, size distribution and downwind grounding of aerosols from Mt. Etna, J. Geophys. Res., 111, D10302, doi:10.1029/2005JD006015, 2006.

Ayers, G. P., Keywood, M. D., Gillet, R. W., Manins, P. C., Malfroy, H., and Bardsley, T.: Validation of passive diffusion samplers for $\mathrm{SO}_{2}$ and $\mathrm{NO}_{2}$, Atmos. Environ., 32, 3593-3600, 1998.

Bobrowski, N., Hönninger, G., Galle, B., and Platt, U.: Detection of bromine monoxide in a volcanic plume, Nature, 423, 273-276, 2003.

Bobrowski, N., von Glasow, R., Aiuppa, A., Inguaggiato, S., Louban, I., Ibrahim, O. W., and Platt, U.: Halogen Chemistry in Volcanic Plumes, J. Geophys. Res., in press, 2007.

Bonaccorso, A., Calvari, S., Coltelli, M., Del Negro, C., and Falsaperla, S. (Eds): Mt. Etna: Volcano Laboratory AGU Geophysical Monograph Series, 143, 2004.

Caltabiano, T., Burton, M., Giammanco, S., Allard, P., Bruno, N., Murè, F., and Romano, R.: Volcanic Gas Emissions From the Summit Craters and Flanks of Mt. Etna, 1987-2000, in: Mt. Etna: Volcano Laboratory AGU Geophysical Monograph Series, edited by: Bonaccorso, A., Calvari, S., Coltelli, M., Del Negro, C., and Falsaperla, S., 143, 111-128, 2004.

Delmelle, P.: Environmental impacts of tropospheric volcanic gas plumes, in Volcanic degassing, edited by: Oppenheimer, C., Pyle, D. and Barclay, J., Geological Society Special Publications, 213, 381-399, 2003.

Delmelle, P., Stix, J., Bourque, C. P. A., Baxter, P. J., Garcia Alvarez, J., and Barquero, J.: Dry deposition and heavy acid loading in the vicinity of Masaya Volcano, a major sulfur and chlorine source in Nicaragua, Environ, Sci. Tecnol., 35, 1289-1293, 2001.

Delmelle, P., Stix, J., Baxter, P. J., Garcia-Alvarez, J., and Barquero, J.: Atmospheric dispersion, environmental effects and potential health hazard associated with the low-altitude gas plume of Masaya volcano, Nicaragua, Bull. Volcanol., 64, 423-434, 2002.

Ferm, M.: The theories behind diffusive sampling, Paper presented at International Conference Measuring Air Pollutants by Diffusive Sampling, Montpellier, France 26-28 September 2001, 3140, 2001.

Francis, P., Burton, M. R., and Oppenheimer, C.: Remote measurements of volcanic gas compositions by solar occultation spectroscopy, Nature, 396, 567-570, 1998.

Frische, M., Garofalo, K., Hansteen, T. H., and Borchers, R.: Fluxes and origin of halogenated organic trace gases from Momotombo volcano (Nicaragua), Geochem. Geophys. Geosys., 7, Q05020, doi:10.1029/2005GC001162, 2006.

Gerlach, T. M.: Volcanic sources of tropospheric ozonedepleting trace gases, Geochem. Geophys. Geosyst., 5, Q09007, doi:10.1029/2004GC000747, 2004.

Horrocks, L. A., Oppenheimer, C., Burton, M. R., and Duffell, H. J.: Compositional variation in tropospheric volcanic gas plumes: evidence from ground-based remote sensing, in Volcanic degassing, edited by C. Oppenheimer, D. Pyle and J. Barclay, Geological Society Special Publications, 213, 349-369, 2003.

Lee, C., Kim, Y. J., Tanimoto, H., Bobrowski, N., Platt, U., Mori, T., Yamamoto, K., and Hong, C. S.: High $\mathrm{ClO}$ and ozone depletion observed in the plume of Sakurajima volcano, Japan. Geophys. Res. Lett., 32 , 21809, doi:10.1029/2005GL023785, 2005.

Martin, D., Ardouin, B., Bergametti, G., Carbonelle, J., FaivrePierret, R., Lambert, G., and Le Cloarec, M. F.: Geochemistry of sulfur in Mt. Etna plume, J. Geophys. Res., 91, 12 249-12 254, 1986.

Martin, R. S., Mather T. A., and Pyle, D.M .: Modeling the chemistry of high temperature mixtures of magmatic and atmospheric gases, Geochem. Geophys. Geosyst., 7, Q04006, doi:10.1029/2005GC001186, 2006.

Mather, T. A., Pyle, D. M., and Oppenheimer, C.: Tropospheric Volcanic Aerosol, in Volcanism and the Earth's Atmosphere, Geophysical Monograph 139, edited by: Robock, A. and Oppenheimer, Am. Geophys. Union, Washington, D.C. 189-212, 2003a.

Mather, T. A., Allen, A. G., Oppenheimer, C., Pyle, D. M., and McGonigle, A. J. S.: Size-resolved characterisation of soluble ions in the particles in the tropospheric plume of Masaya volcano, Nicaragua: Origins and plume processing, J. Atmos.Chem., 46(3), 207-237, 2003b.

McGonigle, A. J. S., Delmelle, P., Oppenheimer, C., Tsanev, V. I., Delfosse, T., Williams-Jones, G., Horton, K., and Mather, T. A.: $\mathrm{SO}_{2}$ depletion in tropospheric volcanic plumes, Geophys. Res. Lett., 31, L13201. doi:10.1029/2004GL019990, 2004.

Métrich, N. and Clocchiatti, R.: Sulfur abundance and its speciation in oxidized alkaline melts, Geochim. Cosmochim. Acta, 60, 4151-4160, 1996.

Nicovich, J. M., Kreutter, K. D., van Dijk, C. A., and Wine, P. H.: Temperature- Dependent Kinetics Studies of the Reactions $\mathrm{Br}\left({ }^{2} \mathrm{P}_{3,2}\right)+\mathrm{H}_{2} \mathrm{~S} \Downarrow \diamond \mathrm{SH}+\mathrm{HBr}$ and $\mathrm{Br}\left({ }^{2} \mathrm{P}_{3,2}\right)+\mathrm{CH}_{3} \mathrm{SH} \Downarrow \diamond$ $\mathrm{CH}_{3} \mathrm{~S}+\mathrm{HBr}$. Heats of Formation of SH and $\mathrm{CH} \neg \mathrm{S}$ Radicals, J. Phys. Chem., 96, 2518-2528, 1992.

Oppenheimer, C., Francis, P., and Stix, J.: Depletion rates of $\mathrm{SO}_{2}$ in tropospheric volcanic plumes, Geophys. Res. Lett., 25, 26712674, 1998.

Oppenheimer, C., Tsanev, V. I., Braban, C. F., Cox, R. A., Adams, J. W., Aiuppa, A., Bobrowski, N., Delmelle, P., Barclay, J., and McGonigle, A. J. S.: BrO formation in volcanic plumes, Geochimica Cosmochimica Acta, 70, 2935-2941, 2006. 
Penkett, S. A., Jones, B. M. R., Brice, K. A., and Eggleton, A. E. J.: The importance of atmospheric ozone and hydrogen peroxide in oxidising sulphur dioxide in cloud and rainwater, Atmos. Environ., 13, 123-137, 1979.

Ravishankara, A. R.: Heterogeneous and multiphase chemistry in the troposphere, Science, 276, 1058-1065, 1997.

Robock, A.: Volcanic Eruptions and Climate, Rev. Geophys., 38, 191-220, doi:10.1029/1998RG000054, 2000

Robock, A. and Oppenheimer, C.: Volcanism and the Earth's atmosphere, AGU Geophysical monograph, 139, doi:10.1029/139GM03, 2003.

Sander, S. P., Friedl, R. R., Golden, D. M., Kurylo, M. J., Moortgat, G. K., Keller-Rudek, H., Wine, P. H., Ravishankara, A. R., Kolb, C. E., Molina, M. J., Finlayson-Pitts, B. J., Huie, R. E., and Orkin, V. L.: Chemical Kinetics and Photochemical Data for Use in Stratospheric Modeling. Technical Report JPL Publication 062, Jet Propulsion Laboratory, Pasadena, CA, 2006.
Schwandner, F. M., Seward, T. M., Gize, A. P., Hall, P. A., and Dietrich, V. J.: Diffuse emission of organic trace gases from the flank and crater of a quiescent active volcano (Vulcano, Aeolian Islands, Italy), J. Geophys. Res., 109(D4), D04301, doi:10.1029/2003JD003890, 2004.

Symonds, R., Rose, W. I., Bluth, G. J. S., and Gerlach, T. M.: Volcanic-gas studies: methods, results and applications, in: Volatiles in Magmas, edited by: Carroll, M. R. and Halloway, J. R., Rev. Mineralogy, 30, 1-66, 1994.

von Glasow, R., Sander, R., Bott, A., and Crutzen, P. J.: Modeling halogen chemistry in the marine boundary layer. 1. Cloudfree MBL, J. Geophys. Res., 107 , 4341, doi:10.1029/2001JD000 942, 2002. 